\title{
The Effect of Technology Use on Employability Perception
}

\author{
Nuh Osman Y1ld1z (Corresponding author) \\ Bolu Abant İzzet Baysal University, Bolu, Turkey \\ Tel: 90-542-212-0141Ｅ-mail: nuhosmanyildiz@gmail.com
}

Received: November 5, 2021 Accepted: December 3, 2021

Published: December 31, 2021

doi:10.5296/jei.v7i3.19273 URL: https://doi.org/10.5296/jei.v7i3.19273

\begin{abstract}
The study aims to examine whether the use of technology has a predictive effect on the employability perceptions of university students studying in the field of sports sciences in terms of variables of gender, department and foreign language knowledge levels. The sample of this study, that aims to examine the predictive effect of the level of technology use of students studying in the field of sports sciences on their perceptions of employability, and to examine these concepts in terms of gender, department, working in the fields of sports sciences and level of foreign language knowledge, consisted of a total of 232 participants, 101 females and 131 males. In the study the "Employability Perception Scale" (EPS) developed by Rothwell et al. (2008) and adapted into Turkish by Karl1 (2016), and the Technology Use Scale (TUS) developed by Zincirkıran and Tiftik (2014) were used. According to the results of the analysis, a significant difference was found in the use of technology in terms of foreign language knowledge $(p<0.05)$. No significant difference was determined in terms of FAI and TSK and other variables. Finally, it was determined that the use of technology had a $22 \%$ effect on the perception of employability. As a result, it is possible to state that the employability perceptions and technology use levels of the students studying in the field of sports sciences are high, and the use of technology is a significant predictor of the employability perception.
\end{abstract}

Keywords: Innovation, Technological development, Personal development

\section{Introduction}

The concept of employability, defined as an individual's ability to maintain the job he has or to get the job he desires (Rothwell \& Arnold, 2007), and the perception of employability, defined as the individual's perception of the possibilities of obtaining and maintaining employment (Vanhercke et al., 2014), are the concepts of recent university graduates. It has 
become a global phenomenon that includes the European Union countries with the increase in unemployment among the European Union (Ayala \& Garcia, 2021). Today, university education is no longer seen as the only factor in employing an individual. Therefore, individuals who are competent in terms of knowledge, skills and experience are needed in an environment where organizations in a war of existence have to cope with increasing quality and quantity on the one hand, and have to keep up with the rapidly globalizing world on the other hand (Kaçay et al., 2020). In this context, in addition to the investment made in education and work experience, competence development can be said to be one of the three components that increase the capacity of individuals to achieve a job or be employable (Karl, 2016). The change environment that we are exposed to every new day is effective in every field, as well as in the perception of employability. The current competitive environment requires integration with all these changes (Yıldız \& Çiftçi, 2021). In the study of Rahmat et al. (2012), the skills of employed graduates were examined and it was determined that the social skills, planning skills, and technology use skills of the employed participants were at high levels. It is possible to say that one of the most important concepts of changing factors in this direction is technological developments.

The use of technological products encountered in daily life is increasing in the field of sports as well as in every field (Yüce at et al., 2020). It is possible to state that the use and adaptation of technology will be effective in finding a job in the future for individuals who are educated in the field of sports. The increase in the use of technology makes it possible to say that technology use competence should be among the qualifications of sports science students and graduates waiting to be employed. The situation in question is gaining importance day by day in terms of evaluating this subject by the individuals in the field, determining whether the use of technology variable is effective in the belief that individuals can be employed, contributing to the literature and shedding light on the higher education institutions that continue their education and training activities in the field of sports sciences during the application phase. In this context, the study aims to examine whether the use of technology has a predictive effect on the employability perceptions of university students studying in the field of sports sciences in terms of gender, department and foreign language knowledge level variables.

\section{Method}

\subsection{Research Method}

This study, which aims to examine the predictive effect of technology use levels of students studying in the field of sports sciences on their perceptions of employability, and to examine these concepts in terms of gender, department, study in sports sciences and foreign language knowledge level variables, was designed according to correlational and causal comparison methods.

\subsection{Study Group}

Simple random sampling method, which is one of the non-random sampling methods, was used to determine the sample of the study. The sample in question comprised of a total of 232 
participants, 101 females (43.5\%) and 131 males (56.5\%).

\subsection{Data Collection Tool}

The measurement tool of the study consists of three parts. In the first part, there are items that question the demographic information of the participants such as age, gender, department, working in the fields of sports sciences and foreign language knowledge level.

In the second part, "Employability Perception Scale" (IEAS) developed by Rothwell et al. (2008) and adapted into Turkish by Karlı (2016), was used. The scale consists of three sub-dimensions, namely "University Prestige", "Confidence in the Field of Study" and "Self-Confidence", and 10 items. The scale is a five-point Likert type and is scored as 1 strongly disagree, 2 disagree, 3 undecided, 4 agree and 5 completely agree. Within the scope of this study, the internal consistency coefficient of the scale was determined as $\alpha=0.91$.

In the third part, the Technology Usage Scale developed by Zincirkıran and Tiftik (2014) was used. The scale consists of three sub-dimensions and 12 items. The sub-dimensions are Novelty Perception, Technology Pursuit, and Technological Madness. The scale is a five-point Likert type and scored as 1 strongly disagree, 2 disagree, 3 undecided, 4 agree and 5 completely agree. Within the scope of this study, the internal consistency coefficient of the scale is $\alpha=0.84$.

\subsection{Analysis of Data}

First, descriptive statistics were applied on the obtained data. Normality test was used to determine whether the data were normally distributed and parametric tests were performed after the data showed normal distribution. Pearson Product Moments Correlation Coefficient (r) was used in order to determine the level of relationship between the variables used in the analysis of the data. Linear Regression Analysis was used to determine the effect of students' technology use on their employability perception. In addition, t-Test in Unrelated Samples and One-Way Analysis of Variance (ANOVA) analyzes were used to examine the employability perception and technology use in terms of gender, department, work in the fields of sports sciences and foreign language knowledge level.

\section{Results}

In this section, findings related to the descriptive statistics of the research participants, perception of employability, and the results of the analysis of the relationship and impact level regarding the use of technology, as well as the analysis of the data on the study of students' employability perceptions and technology use in terms of gender, department, work in the fields of sports sciences and foreign language knowledge level variables were reported. 


\section{Macrothink}

Table 1. Demographic information of the participants

\begin{tabular}{|l|l|l|l|}
\hline Demographic variable & Subgroup & Frequency & Percent (\%) \\
\hline \multirow{5}{*}{ Gender } & Female & 101 & 43.5 \\
\cline { 2 - 4 } & Male & 131 & 56.5 \\
\cline { 2 - 4 } & Total & 232 & 100.0 \\
\hline Age & $18-25$ & $232(\bar{x}=21.08)$ & 100.0 \\
\hline \multirow{5}{*}{ Department } & Coaching & 65 & 28.0 \\
\cline { 2 - 4 } & P.E. and Sports Teaching & 51 & 22.0 \\
\cline { 2 - 4 } & Sports Management & 97 & 41.8 \\
\cline { 2 - 4 } & Recreation & 19 & 8.2 \\
\cline { 2 - 4 } & Total & 232 & 100.0 \\
\hline \multirow{5}{*}{ Foreign Language Level } & Bad & 96 & 41.4 \\
\cline { 2 - 4 } & Middle & 114 & 49.1 \\
\cline { 2 - 4 } & Good & 22 & 9.5 \\
\cline { 2 - 4 } & Total & 232 & 100.0 \\
\hline
\end{tabular}

When the table is examined, it is possible to say that $101(43.5 \%)$ of the participants were female, 131 (56.5\%) were male, their average age was 21.08, the age range was between 18 and 25, 65 of them had Coaching Education, 51 of them had education in Sports Teaching, 97 of them were in Sports Management, 19 of them were in Recreation, 96 of them had bad level of foreign language, 114 of them had medium level and 22 of them had good level of foreign language.

Table 2. Findings related to the comparison of Employability Perception Scale and Technology Use Scale in terms of gender variable

\begin{tabular}{|l|l|l|l|l|l|l|l|}
\hline Dimension & Gender & $\mathbf{n}$ & Avg. & SS & SD & t & P \\
\hline \multirow{2}{*}{ Employability Perception } & Female & 101 & 3.4376 & .74590 & \multirow{2}{*}{230} & \multirow{2}{*}{.720} & \multirow{2}{*}{.472} \\
\cline { 2 - 8 } & Male & 131 & 3.3573 & .91054 & & & \\
\hline \multirow{2}{*}{ Technology Use } & Female & 101 & 2.9332 & .59547 & \multirow{2}{*}{230} & -.203 & .839 \\
\cline { 2 - 9 } & Male & 131 & 2.9523 & .78888 & & & \\
\hline
\end{tabular}


When the table is examined, no significant difference was determined regarding the gender variable in the total scores of the students on the Perception of Employability Scale $\left(\mathrm{t}_{(232)}=\right.$ $0.720 p>0.05)$ and the Technology Use Scale $\left(t_{(232)}=-0.203\right.$ and $\left.p>0.05\right)$.

Table 3. Findings on the Comparison of Employability Perception Scale and Technology Use Scale in terms of department variable

\begin{tabular}{|c|c|c|c|c|c|c|c|}
\hline Dimension & Gender & $\mathbf{n}$ & Avg. & SS & SD & $\mathbf{F}$ & $\mathbf{p}$ \\
\hline \multirow{4}{*}{ Employability Perception } & Coaching & 65 & 3.32 & .92 & \multirow{4}{*}{ 3. 228} & \multirow{4}{*}{1.634} & \multirow{4}{*}{.182} \\
\hline & P.E.S.T. & 51 & 3.44 & .70 & & & \\
\hline & S. Management & 97 & 3.48 & .81 & & & \\
\hline & Recreation & 19 & 3.04 & .98 & & & \\
\hline \multirow{4}{*}{ Technology Use } & Coaching & 65 & 2.87 & .67 & \multirow{4}{*}{ 3. 228} & \multirow{4}{*}{1.770} & \multirow{4}{*}{.154} \\
\hline & P.E.S.T. & 51 & 3.04 & .77 & & & \\
\hline & S. Management & 97 & 2.99 & .70 & & & \\
\hline & Recreation & 19 & 2.65 & .60 & & & \\
\hline
\end{tabular}

When the table is examined, no significant difference was determined in the total of Employability Perception Scale in terms of department variable $\left.\mathrm{F}_{(3.228)}=1.634, \mathrm{p}>0.05\right)$. There was also no significant difference in the total of the Technology Use Scale in terms of the department variable $\left.\mathrm{F}_{(3.228)}=1.770, \mathrm{p}>0.05\right)$.

Table 4. Findings related to the comparison of Employability Perception Scale and Technology Use Scale in terms of foreign language knowledge variable

\begin{tabular}{|c|c|c|c|c|c|c|c|c|}
\hline Dimension & Foreign Language Level & $\mathbf{n}$ & Avg. & SS & SD & $\mathbf{F}$ & $\mathbf{p}$ & Sig. \\
\hline \multirow{3}{*}{ Employability Perception } & Bad & 96 & 3.25 & .84 & & \multirow{3}{*}{2.476} & \multirow{3}{*}{.086} & \multirow{3}{*}{-} \\
\hline & Middle & 114 & 3.51 & .81 & 2. 229 & & & \\
\hline & Good & 22 & 3.35 & .92 & & & & \\
\hline \multirow{3}{*}{ Technology Use } & $\mathrm{Bad}$ & 96 & 2.74 & .62 & & \multirow{3}{*}{6.589} & \multirow{3}{*}{.002} & Bad \\
\hline & Middle & 114 & 3.08 & .72 & 2.229 & & & - \\
\hline & Good & 22 & 3.06 & .79 & & & & Good \\
\hline
\end{tabular}




\section{Ml Macrothink}

When the table is examined, while no significant difference was determined in terms of foreign language knowledge variable in the total of Employability Perception Scale $F_{(2.229)}=$ 2.476, $p>0.05)$, the significant difference was determined in the total of the Technology Use Scale $\left(\mathrm{F}_{(2.229)}=2.476, \mathrm{p}<0.05^{*}\right)$. Hochberg's GT2 (Field, 2009), which is used in cases where the sample numbers are not equal, was used to determine from which group the said difference originated. As a result of the test, it was concluded that the students with good level of foreign language knowledge had higher technology usage levels than the students with bad language knowledge.

Table 5. Investigation of the Relationship Between Variables by Pearson Product-Moment Correlation

\begin{tabular}{|l|l|}
\hline & Technology Use \\
\hline Employability Perception & $0.47^{* *}$ \\
\hline
\end{tabular}

Note. $\mathrm{p}<0.01$.

Considering the table, it is seen that there is a positive and moderate relationship (Gürbüz \& Şahin, 2020) between Perception of Employability and Use of Technology $\left(r_{(232)}=0.47, p<\right.$ $0.01)$.

Table 6. Regression Analysis Results for Predicting Employability Perception

\begin{tabular}{|l|l|l|l|l|l|l|}
\hline \multicolumn{2}{|l|}{ Variables } & B & Standard error & Standardize $\boldsymbol{\beta}$ & $\mathbf{p}$ & $\mathbf{R}^{\mathbf{2}}$ \\
\hline Technology Use & Employability Perception & 0.55 & 0.06 & 0.467 & 0.00 & 0.22 \\
\hline
\end{tabular}

Note. ${ }^{*} \mathrm{p}<.05$.

The results of the analysis show that there is a statistically significant effect on the relationship between technology use and the perception of employability $(\beta=0.467 ; p<.05)$. Considering the value of the model, it can be stated that $22 \%$ of the employability perception is explained by the use of technology.

\section{Discussion}

When the research findings were examined, it was determined that the gender variable had not a significant effect on the perception of employability and the level of technology use. When the relevant literature is examined, Aksoy (2018), Yıldırım et al. (2018), and Güneş and Buluç (2017) examined the technology use levels of university students and no significant difference was found in terms of gender variable. The studies in the literature and the findings of this study support each other. Examining the studies on employability and 
gender variable, Qenani et al. (2014) revealed in his analysis of the employability perceptions of university students that their employability perceptions differ according to their gender. In the study of Vargas et al. (2018), the perception of employability was examined and a significant difference was determined in terms of gender variable. It was concluded that the said difference was in favor of male participants. The developer of the scale Rothwell et al. (2009), also determined a significant difference in the perception of employability in terms of gender variable. It was concluded that the said difference was in favor of female participants. In the studies conducted by Karl1 (2016), and Taze and Karayol (2020), the perception of employability was examined, and as in the findings of this study, no significant difference was determined in terms of gender variable. When the relevant literature is examined, it is observed that different results are obtained in different studies. The result of this study is thought to be due to the belief that individuals can do any job in every field, regardless of gender, and the employment of students studying in the field of sports in different sports organizations during their education period.

Employability Perception was examined in terms of the department variable and no significant difference was determined. In the study conducted by Taze and Karayol (2020), the perception of employability of sports science students in terms of their education was examined and no significant difference was determined. The results of this study are in agreement with the results available in the literature. Today, the fact that students studying in the field of sports sciences have the opportunity to work in each other's fields due to joint courses in the field of sports sciences, formation training and coaching courses opened by federations can be considered as the source of this result.

No significant difference was determined in terms of department variable in the level of Technology Use. When the literature was reviewed, in a study conducted by Sivrikaya and Biricik (2019), the use of information and communication technologies by sports science students was examined and no significant difference was determined in terms of department variable. The results obtained in this study and the aforementioned study support each other. It is thought that the result of this study can be due to the active use of technology in sports or in every field in daily life, as well as the fact that the courses for the use of technology in the curriculum of the students are common courses.

The Perception of Employability and the variable of foreign language knowledge were examined and no significant difference was determined. When the relevant literature is examined, a study by Karl (2016) also examined the perception of employability in terms of foreign language use, and no significant difference was found. The results of the two studies support each other. The reason for this situation can be thought to be due to the fact that the number of participants who speak a foreign language at a good level in the sample is less than the others. It is thought that it can be re-examined in other studies by increasing the sample.

When the use of technology and foreign language knowledge were examined, a significant difference was determined. When the said difference is examined, it has been concluded that the technology usage levels of the students with good foreign language knowledge level are higher than the students with bad level of foreign language. The relevant literature was 
searched and no study could be found on the subject. It is thought that the result of this study will shed light on similar studies. It is thought that the source of this difference is that the language of use of current technology products, software programs and applications is not Turkish and that the participants with foreign language knowledge are more motivated to use technology.

A positive and moderate relationship was determined between the Perception of Employability and Use of Technology. Bernston et al. (2006), De Vos et al. (2011), and Karl1 (2016) stated that there is a positive relationship between competence development and employability. Considering that concepts such as technology use and technology literacy are also a skill and a competence, the studies in question and the results of this study support each other.

It was determined that the use of technology had a significant predictive effect on the perception of employability. Kokocak et al. (2015), was stated that technological developments play a role in reducing employment in the short term and creating employment in the long term, and are effective in the emergence of subsidiary branches and in increasing employment. In different studies conducted by Çelik (2006) and İçli (2001), it has been stated that the employment rate of individuals who adapt and use technological developments is higher. Rahmat et al. (2012) examined the skills of employed graduates and it was determined that the social skills, planning skills and technology use skills of the employed participants were at a high level. When the studies in the literature are examined, it has been determined that the use of technology has an effect on employability, as in the result of this study. It is thought that this effect can be due to the participants' use of technology and technological products during the training they received in the field of sports sciences.

\section{Conclusion}

As a result, it is possible to state that the employability perceptions and technology use levels of the students studying in the field of sports sciences are high, and the use of technology is a significant predictor of the employability perception.

\section{References}

Aksoy, C. (2018). Teknoloji Kullanım Ölçeğinin Geçerlilik ve Güvenilirliğinin Ölçülmesi: Üniversite Öğrencilerine Yönelik Bir Araştırma. OPUS Uluslararası Toplum Araştırmaları Dergisi, 8(15), 1111-1131. https://doi.org/10.26466/opus.419032

Ayala Calvo, J. C., \& Manzano García, G. (2021). The influence of psychological capital on graduates' perception of employability: The mediating role of employability skills. Higher Education Research \& Development, 40(2), 293-308. https://doi.org/10.1080/07294360.2020. 1738350

Bernston, E., Sverke, M., \& Marklund, S. (2006). Predicting Perceived Employability: Human Capital or Labour Market Opportunities. Econ Ind. Democracy, 27(2), 223-244. https://doi.org/10.1177/0143831x06063098

Çelik, A. (2006). Bir istihdam politikasi olarak girişimcilik. Uluslararası Girişimcilik 
Kongresi (pp. 467-476). Kırgızistan-Türkiye Manas Üniversitesi Yayınları.

De Vos, A., De Haw, S., \& Van Der Heijden, B. I. J. M. (2011). Competency Development and Career Success: The Mediating Role of Employability. J. Vocat. Behav., 79, 438-447. https://doi.org/10.1016/j.jvb.2011.05.010

Güneş, A. M., \& Buluç, B. (2017). Sınıf öğretmenlerinin teknoloji kullanımları ve öz yeterlilik inançları arasındaki ilişki. Tübav Bilim Dergisi, 10(1), 94-113.

Kaçay, Z., Güngör, N. B., Yenel, F., \& Soyer, F. (2020). The Effect of Work Engagement and Mindfulness on Organizational Behavior. Journal of Educational Issues, 6(2). https://doi.org/ 10.5296/jei.v6i2.17975

Karli, U. (2016). Adaptation and Validation of Self-Perceived Employability Scale: An Analysis of Sports Department Students and Graduates. Educational Research and Reviews, 11(8), 848-859. https://doi.org/10.5897/ERR2016.2712

Kökocak, A., Yılmaz, M., \& Demirci, N. (2015). İşsizlik Olgusu ve İstihdam Artırıcı Stratejiler. Alanya Isletme Fakültesi Dergisi, 7(1).

Qenani, E., MacDougall, N., \& Sexton, C. (2014). An Empirical Study of Self- Perceived Employability: Improving the Prospects for Student Employment Success in an Uncertain Environment. Active Learn. High Educ, 15(3), 199-213. https://doi.org/10.1177/14697874 14544875

Rahmat, M., Ahmad, K., Idris, S., \& Zainal, N. F. A. (2012). Relationship between employability and graduates' skill. Procedia-Social and Behavioral Sciences, 59, 591-597. https://doi.org/10.1016/j.sbspro.2012.09.318

Rothwell, A., \& Arnold, J. (2007). Self-perceived Employability: Development and Validation of a Scale. Personnel Review, 36(1), 23-41. https://doi.org/10.1108/004834807 10716704

Rothwell, A., Herbert, I., \& Rothwell, F. (2008). Self-perceived employability: Construction and initial validation of a scale for university students. Journal of Vocational Behavior, 73(1), 1-12. https://doi.org/10.1016/j.jvb.2007.12.001

Rothwell, A., Jewell, S., \& Hardie, M. (2009). Self-perceived employability: Investigating the responses of post-graduate students. Journal of Vocational Behavior, 75(2), 152-161. https://doi.org/10.1016/j.jvb.2009.05.002

Sivrikaya, M. H., \& Biricik, Y. S. (2019). Dijital çağda bilgi ve iletişim teknolojilerinin kullanımı: spor bilimleri fakültesi öğrencileri üzerine bir uygulama. Beden Ĕ̆itimi ve Spor Bilimleri Dergisi, 21(3), 148-156.

Taze, M., \& Karayol, M. (2020). Investigation of Entrepreneurship Levels and Employability Perception of Undergraduate Students Studying Sports Sciences. International Education Studies, 13(5), 35-43. https://doi.org/10.5539/ies.v13n5p35

Vanhercke, D., Cuyper, N., Peeters, E., \& De Witte, H. (2014). Defining Perceived 


\section{Macrothink}

Employability: A Psychological Approach. Personnel Review, 43(4), 592-605. https://doi.org/ 10.1108/PR-07-2012-0110

Vargas, R., Sánchez-Queija, M. I., Rothwell, A., \& Parra, A. (2018). Self-perceived employability in Spain. Education+ Training, 60(3), 226-237. https://doi.org/10.1108/ET-032017-0037

Yıldırım, E., Uğurlu, M. F., \& Gözüböyük, K. (2018). Spor Bilimleri Fakültesinde Öğrenim Gören Öğrencilerin Eğitimde Teknoloji Kullanımına İlişkin Tutum ve Düşünceleri. Turkish Studies, 13/21, 189-198. https://doi.org/10.7827/Turkishstudies.13967

Yıldız, N. O., \& Çiftçi, S. (2021). Spor işletmelerinde hedef belirleme süreci: Dalış okulları örneği. Ankara, Gazi Kitabevi.

Yüce, A., Aydoğdu, V., Katırcı, H., \& Gökçe Yüce, S. (2020). Giyilebilir teknolojik spor ürünleri kullanım algısı ölçeği: Bir ölçek uyarlama çalışması. Spormetre Beden Eğitimi ve Spor Bilimleri Dergisi, 18(4), 113-124. https://doi.org/10.33689/spormetre.681835

Zincirkiran, M., \& Tiftik, H. (2014). Innovation or technological madness? a research on the students of business administration for their preferences of innovation and technology. International Journal of Academic Research in Business and Social Sciences, 4(2), 320. https://doi.org/10.6007/IJARBSS/v4-i2/651

\section{Copyright Disclaimer}

Copyright for this article is retained by the author(s), with first publication rights granted to the journal.

This is an open-access article distributed under the terms and conditions of the Creative Commons Attribution license (http://creativecommons.org/licenses/by/3.0/). 